\title{
Peningkatan Kemampuan Menganalisis Unsur-unsur Pembangun Cerpen Melalui Model Discovery Learning pada Siswa
}

\author{
Rosana Rosana ${ }^{1}$, Yessi Fitriani ${ }^{2}$, Darwin Effendi ${ }^{2}$ \\ ${ }^{1}$ Sekolah Menengah Atas Negeri 1 Tanjung Batu, Indonesia \\ ${ }^{2}$ Universitas PGRI Palembang, Indonesia
}

\begin{tabular}{|c|c|}
\hline Article Info & ABSTRACT \\
\hline Article history: & Penelitian tindakan kelas ini dilakukan dengan tujuan untuk meningkatkan \\
\hline Received May $15^{\text {th }}, 2021$ & kemampuan menganalisis unsur-unsur pembangun cerpen melalui model \\
\hline Revised Jun $18^{\text {th }}, 2021$ & $\begin{array}{l}\text { discovery learning pada siswa kelas XI di SMA Neger1 I Tanjung Batu. Dalam } \\
\text { melakukan nenoumpulan data neneliti mengounakan teknik }\end{array}$ \\
\hline Accepted Jul 23 ${ }^{\text {th }}, 2021$ & $\begin{array}{l}\text { Penelitian ini dilakukan dalam tiga siklus dan masing-masing siklus memiliki } \\
\text { tahapan yakni perencanaan, tindakan, observasi, dan refleksi. Berdasarkan }\end{array}$ \\
\hline Keyword: & $\begin{array}{l}\text { hasil analisis data diperoleh kesimpulan bahwa model pembelajaran discovery } \\
\text { learning dapat meningkatkan kemampuan menganalisis unsur-unsur }\end{array}$ \\
\hline Discovery learning & pembangun cerpen siswa kelas XI IPS-3 SMA Negeri 1 Tanjung Batu. \\
\hline Kemampuan menganalisis & Penelitian ini memberi kontribusi kepada guru Bahasa Indonesia agar \\
\hline Unsur-unsur pembangun & menggunakan model discovery learning untuk meningkatkan kemampuan \\
\hline Cerpen & siswa dalam menganalisis unsur-unsur pembangun cerpen. \\
\hline
\end{tabular}

Bahasa Indonesia

\section{Corresponding Author:}

Rosana, R.,

Sekolah Menengah Atas Negeri 1 Tanjung Batu, Indonesia

Email: rosanamakmun71@gmail.com

\section{Pendahuluan}

Salah satu mata pelajaran Bahasa Indonesia yang menjadi perhatian di SMA adalah menganalisis unsur-unsur pembangun cerpen. Cerpen atau istilahnya cerita pendek adalah salah satu bentuk karya fiksi. Cerita pendek sesuai dengan namanya, memperlihatkan sifat yang serba pendek, baik peristiwa yang diungkapkan, isi cerita, jumlah pelaku, dan jumlah kata yang digunakan. Perbandingan ini jika dikaitkan dengan bentuk prosa yang lain, misalnya novel.

Kosasi (2010) menjelaskan pada umumnya cerita pendek merupakan cerita yang habis dibaca sekitar sepuluh menit atau setengah jam. Jumlah katanya sekitar 500-5.000 kata. Cerita pendek bukan ditentukan oleh banyaknya halaman untuk mewujudkan cerita tersebut atau sedikitnya tokoh yang terdapat dalam cerita itu, melainkan lebih disebabkan oleh ruang lingkup permasalahan yang ingin disampaikan oleh bentuk karya sastra tersebut. Jadi sebuah cerita yang pendek belum tentu digolongkan ke dalam jenis cerita pendek. Jika ruang lingkup permasalahan yang diungkapkan tidak memenuhi persyaratan yang dituntut oleh cerpen (Effendi, 2019).

Sementara Sadikin (2010) mengemukakan bahwa sesuai namanya cerita pendek dapat diartikan sebagai cerita yang berbentuk prosa naratif fiktif, cenderung padat, dan langsung pada tujuannya. Selanjutnya Suherli, (2017) dalam bukunya menjelaskan bahwa untuk memahami isi suatu cerpen, kita sebaiknya mengawalinya 
dengan sejumlah pertanyaan. Dengan demikian, pemehaman kita terhadap cerpen itu akan lebih terfokus dan lebih mendalam. Ketika pembaca mengapresiasikan salah satu judul cerpen atau cerita pendek, setelah pembaca melaksanakan kegiatan membaca terhadap keseluruhan cerpen itu, pembaca lebih lanjut menampilkan pertanyaan-pertanyaan, misalnya cara penokohannya, setting nya, perwatakan setiap tokoh dan pertanyaan tentang unsur intrinsik lain yang terdapat dalam cerpen itu, pembaca kembali membaca ulang (Purnami, 2012).

Sebuah cerpen memiliki unsur-unsur yang membangun yakni unsur intrinsik dan ekstrinsik. Unsur intrinsik meliputi alur, tema, penokohan, dan latar. Menurut Mulyadi (2017) alur merupakan rangkaian peristiwa yang direka dan dijalin dengan seksama yang menggerakkan jalan cerita melalui kerumitan ke arah klimaks dan penyelesaian untuk mencapai efek tertentu. Urutan peristiwa dapat dimulai dari mana saja, misalnya dari konflik yang telah meningkat, tidak harus bermula dari tahap perkenalan tokoh atau latar. Meskipun ada unsur perkenalan tokoh dan latar, biasanya tidak berkepanjangan. Berhubung beralur tunggal, konflik yang dibangun dan klimaks yang akan diperoleh pun, biasanya, bersifat tunggal pula. Cerpen juga hanya berisi satu tema dikarenakan keadaan alur yang tunggal dan pelaku yang terbatas. Selanjutnya penokohan menurut Suhita dan Purwahida (2018) untuk menggambarkan watak tokoh ada tiga hal yang biasa dilakukan pengarang, yaitu berdasarkan dimensi fisiologis, dimensi psikologis, dimensi sosiologis. Sedangkan latar merupakan keterangan mengenai waktu, ruang, dan suasana terjadinya lakuan dalam karya sastra.

Unsur ekstrinsik adalah faktor luar yang mempengaruhi pengarang pada saat penciptaan cerita, seperti kondisi sosial, ekonomi, ideologi, politik, budaya, agama, dan lain-lain. Unsur ekstrinsik adalah unsur-unsur yang berada di luar karya sastra itu, tetapi secara tidak langsung mempengaruhi bangunan atau sistem organisasi karya sastra. Rahmanto (2010) mengemukakan bahwa Terdapat tiga hal utama dalam unsur ekstrinsik cerpen, yaitu latar belakang masyarakat, latar belakang pengarang, dan nilai-nilai yang terkandung dalam cerpen.

Pada umumnya pembelajaran menganalisis cerpen yang diberikan di sekolah kurang bervariasi, sehingga proses pembelajaran menjadi monoton. Guru seharusnya mampu mengimplementasikan proses pembelajaran itu dengan cara memvariasikan teknik, strategi atau cara agar proses pembelajaran yang disampaikan kepada siswa tidak jenuh dan bosan pada saat menerima materi pelajaran yang diberikan.

Selama ini peneliti dalam menyampaikan materi pembelajaran khususnya membaca cerpen menggunakan metode ceramah dan penugasan. Dari hasil yang diperoleh pada pembelajaran menganalisis unsur-unsur pembangun cerpen yang terdapat pada silabus pembelajaran siswa kelas XI di SMA Negeri 1 Tanjung Batu Kabupaten Ogan Ilir dengan metode ceramah dan penugasan yakni 11 orang siswa $(36,67 \%)$ hanya memperoleh nilai rata-rata sebesar 63, selebihnya (63,33\%) masih di bawah 63. Mengacu kepada KKM yang ada di SMA Negeri 1 Tanjung Batu Kabupaten Ogan Ilir adalah sebesar 70. Artinya kemampuan menganalisis unsur-unsur pembangun cerpen pada siswa kelas XI SMA Negeri 1 Tanjung Batu Kabupaten Ogan Ilir belum mencapai keberhasilan yang diharapkan. Kondisi pembelajaran yang demikian menyebabkan kurang terciptanya suasana yang menyenangkan bagi siswa untuk belajar, menjadikan siswa kurang bersemangat dalam pembelajaran sehingga proses pembelajaran yang diberikan kurang aktif, kurang kreatif dan tidak menyenangkan.

Agar adanya peningkatan kemampuan kemampuan literasi pada pokok bahasan menganalisis unsur-unsur pembangun cerpen pada siswa kelas XI SMA Negeri 1 Tanjung Batu Kabupaten Ogan Ilir perlu adanya model pembelajaran yang menarik bagi siswa. Salah satu model pembelajaran yang dipilih adalah model Discovery Learning. Model pembelajaran ini Discovery/Inquiry Learning adalah memahami konsep, arti, dan hubungan melalui proses intuitif untuk akhirnya sampai kepada suatu kesimpulan. Discovery terjadi bila individu terlibat terutama dalam penggunaan proses mentalnya untuk menemukan beberapa konsep dan prinsip (Nabila, 2018).

Hal ini sejalan dengan Implementasi Kurikulum 2013 menurut Permendikbud Nomor 22 Tahun 2016 tentang Standar Proses menggunakan tiga model pembelajaran yang diharapkan dapat membentuk perilaku saintifik, sosial serta mengembangkan rasa keingintahuan. Ketiga model tersebut adalah model pembelajaran melalui penemuan, model pembelajaran berbasis masalah, dan model pembelajaran berbasis proyek.

Menurut Darmawan dan Wahyudin (2018) discovery learning dapat dipahami sebagai proses pembelajaran yang mampu menempatkan dan memerankan peserta didik sehingga lebih mampu menyelesaikan permasalahan yang ada sesuai dengan pokok materi yang dipelajarinya sesuai dengan kerangka pembelajaran yang disuguhkan oleh guru. Wijaya (2019) menjelaskan Model pembelajaran Discovery Learning atau Penemuan diartikan pula sebagai model pembelajaran yang memberikan pengalaman kepada peserta didik untuk menemukan sesuatu dari proses penyelidikan yang dilakukannya. Pelaksanaan pembelajaran menggunakan model discovery didasarkan pada langkah-langkah yakni memberi stimulus kepada peserta didik, 
mengidentifikasi masalah, mengumpulkan data, mengelompokkan data, memverifikasi, dan menyimpulkan. Dalam mengaplikasikan model pembelajaran discovery learning atau penemuan guru berperan sebagai pembimbing dengan memberikan kesempatan kepada siswa untuk belajar secara aktif, sebagaimana pendapat guru harus dapat membimbing dan mengarahkan kegiatan belajar siswa sesuai dengan tujuan yang dicitacitakan (Sardiman, 2012).

Berdasarkan uraian di atas, peneliti menganggap perlu melakukan penelitian untuk meningkatkan kemampuan menganalisis unsur-unsur pembangun cerpen melalui model discovery learning pada siswa kelas XI di SMA Negeri 1 Tanjung Batu. Penelitian ini baru, karena peneliti belum pernah menemukan kajian yang sama, terutama di daerah Tanjung Batu. Penelitian ini memberi kontribusi kepada guru Bahasa Indonesia agar menggunakan model discovery learning untuk meningkatkan kemampuan siswa dalam menganalisis unsur-unsur pembangun cerpen (Amirullah, 2019) (Nabila, 2018).

\section{Metode}

Penelitian ini merupakan penelitian tindakan kelas. Subjek dalam penelitian ini adalah siswa kelas XI IPS-3 SMA Negeri 1 Tanjung Batu dengan jumlah siswa sebanyak 30 orang dan objek yang dijadikan kajian penelitian adalah kemampuan menganalisis unsur-unsur pembangun cerpen melalui model discovery learning. Langkah-langkah operasional penelitian meliputi tahap persiapan, tahap perencanaan, tahap pelaksanaan tindakan, tahap observasi, serta tahap refleksi (Sugiyono, 2015). Penelitian ini dilaksanakan dalam tiga siklus.Dalam melakukan pengumpulan data peneliti menggunakan teknik observasi dan tes. observasi dalam penelitian tindakan kelas ini yaitu dengan melakukan pengamatan selama proses pembelajaran berlangsung. Pengamatan dilakukan aktivitas pada saat pembelajaran menganalisis unsur-unsur pembangun cerpen melalui model discovery learning guna melihat perkembangan sebelum dan sesudah dilakukan tindakan. Sedangkan tes dalam penelitian ini yakni yang berkaitan dengan peningkatan kemampuan menganalisis unsur-unsur pembangun cerpen melalui model discovery learning pada siswa kelas XI di SMA Negeri 1 Tanjung Batu.

\section{Hasil dan Pembahasan}

Berdasarkan hasil observasi pelaksanaan pembelajaran menganalisis unsur-unsur pembangun cerpen melalui model discovery learning pada siswa kelas XI SMA Negeri 1 Tanjung Batu, dapat peneliti uraikan pada tabel berikut ini.

Tabel 1. Keaktifan Siswa dalam Pembelajaran Menganalisis Unsur-unsur Pembangun Cerpen Melalui Model Discovery Learning Pada Tindakan Siklus 1

\begin{tabular}{|c|c|c|c|}
\hline \multirow[t]{2}{*}{ No. } & \multirow[t]{2}{*}{ Keterlibatan Siswa dalam Pembelajaran } & \multicolumn{2}{|c|}{ Siklus 1} \\
\hline & & Jumlah Siswa & Persentase \\
\hline 1 & Terlibat Aktif & 12 & $40 \%$ \\
\hline 2 & Terlibat Pasif & 9 & $30 \%$ \\
\hline 3 & Tidak Terlibat & 9 & $30 \%$ \\
\hline & Jumlah & 30 & $100 \%$ \\
\hline
\end{tabular}

Berdasarkan hasil observasi keaktifan dalam pembelajaran menganalisis unsur-unsur pembangun cerpen melalui model discovery learning pada siswa kelas XI IPS-3 SMA Negeri 1 Tanjung Batu pada siklus 1 yang digunakan belum berjalan secara optimal dan diserap siswa, dikarenakan pembelajaran dalam menganalisis unsur-unsur pembangun cerpen kemungkinan besar siswa kurang tertarik dengan materi tersebut. Keaktifan siswa dalam proses pembelajaran pada tindakan siklus 1 siswa terlibat aktif sebanyak 12 orang siswa atau $40 \%$, terlibat pasif sebanyak 9 orang siswa atau 30\%, dan tidak terlibat sebanyak 9 orang siswa atau 30\%.

Sementara, berdasarkan hasil data tes kemampuan menganalisis unsur-unsur pembangun cerpen melalui model discovery learning pada siswa pada tindakan siklus 1 diperoleh nilai secara keseluruhan sebesar 2035 dengan rata-rata 67,83. Siswa yang tuntas dalam pembelajaran berdasarkan KKM ( $\geq 70$ ) sebanyak 14 orang siswa dengan rata-rata ketuntasan siswa sebesar 46,67\%. Artinya dalam tindakan siklus 1 belum mencapai ketuntasan. Dengan demikian, hasil penelitian pada tindakan siklus 1 dapat dikatakan kemampuan menganalisis unsur-unsur pembangun cerpen melalui model discovery learning pada siswa kelas XI IPS-3 SMA Negeri 1 Tanjung Batu belum ada peningkatan berdasarkan KKM yang ditetapkan yaitu $\geq 70$.

Peneliti mengevaluasi ada beberapa kekurangan dalam proses tindakan, yaitu: (1) siswa belum maksimal bekerjasama dalam kelompok, (2) siswa yang lemah belum terbantu dalam menyelesaikan masalah, (3) siswa yang dianggap pandai belum mampu memberikan bimbingan sesama teman sebaya, (4) rasa harga diri siswa 
yang tinggi, (5) penerimaan perbedaan individu lebih besar, (6) sikap apatis siswa belum mengindikasikan ke arah yang lebih baik, (7) pemahaman materi belum mendalam, (8) motivasi belajar belum optimal, (9) dalam proses pembelajaran siswa masih ketergantungan kepada guru, (10) siswa yang ahli enggan untuk menjadi pemimpin kelompok, (11) kurangnya kerjasama dengan kelompok lain; (12) siswa masih bekerja secara sendiri-sendiri.

Berdasarkan hasil yang dicapai pada tindakan siklus 1, peneliti melanjutkan pada tindakan berikutnya, yaitu tindakan pada siklus 2. Proses pelaksanaan pada siklus 2 adalah menindaklanjuti kekurangan yang terdapat pada tindakan siklus 1 . Kegiatan utama yang dilakukan siswa pada siklus 2 adalah memperbaiki proses pembelajaran yang dilakukan dengan cara menekankan pada model discovery learning. hasil observasi pelaksanaan pembelajaran sspada siklus 2, dapat diuraikan pada tabel berikut ini.

Tabel 2. Keaktifan Siswa dalam Proses Pembelajaran Menganalisis Unsur-unsur Pembangun Cerpen Melalui Model Discovery Learning Pada Tindakan Siklus 2

\begin{tabular}{|c|c|c|c|}
\hline \multirow[t]{2}{*}{ No. } & \multirow[t]{2}{*}{ Keterlibatan Siswa dalam Pembelajaran } & \multicolumn{2}{|c|}{ Siklus 2} \\
\hline & & Jumlah Siswa & Persentase \\
\hline 1 & Terlibat Aktif & 24 & $80 \%$ \\
\hline 2 & Terlibat Pasif & 4 & $13,33 \%$ \\
\hline 3 & Tidak Terlibat & 2 & $6,67 \%$ \\
\hline & Jumlah & 30 & $100 \%$ \\
\hline
\end{tabular}

Berdasarkan hasil observasi keaktifan dalam pembelajaran menganalisis unsur-unsur pembangun cerpen melalui model discovery learning pada siklus 2 yang digunakan belum berjalan secara optimal dan diserap siswa, dikarenakan kemungkinan besar siswa kurang tertarik dengan materi tersebut. Keaktifan siswa dalam proses pembelajaran pada tindakan siklus 2 siswa terlibat aktif sebanyak 24 orang siswa atau $80 \%$, terlibat pasif sebanyak 4 orang siswa atau $13,33 \%$, dan tidak terlibat sebanyak 2 orang siswa atau $6,67 \%$. Sedangkan berdasarkan hasil data tes kemampuan menganalisis unsur-unsur pembangun cerpen melalui model model discovery learning pada siswa pada tindakan siklus 2, diperoleh hasil sebesar 2135 dengan rata-rata 71,17. Siswa yang mencapai ketuntasan sebanyak 24 orang siswa atau rata-rata ketuntasan sebesar $80,00 \%$. Dengan demikian, hasil penelitian pada tindakan siklus 2 dapat dikatakan kemampuan menganalisis unsur-unsur pembangun cerpen melalui model discovery learning pada siswa kelas XI IPS-3 SMA Negeri 1 Tanjung Batu belum meningkat secara signifikan dikarenakan berdasarkan KKM yang ditetapkan yaitu $\geq 70$ dengan ketuntasan siswa dalam proses pembelajaran sebesar $85 \%$.

Belum signifikannya kemampuan menganalisis unsur-unsur pembangun cerpen melalui model discovery learning pada siswa pada tindakan siklus 2, dapat diasumsikan bahwa masih ada beberapa kekurangan dalam proses tindakan, yaitu: (1) Kerja sama siswa dalam kelompok masih ada yang belum maksimal, (2) siswa yang belum mampu menyerap materi pembelajaran yang disampaikan oleh tim ahli belum terbantu dalam menyelesaikan masalah, (3) siswa yang dianggap pandai belum sepenuhnya membimbing siswa lain, (4) motivasi belajar siswa belum mengindikasikan secara maksimal, (5) proses pembelajaran siswa dalam kelompoknya masih belum maksimal, (6) kurangnya kerjasama dengan kelompok lain. Dengan demikian, peneliti melanjutkan tindakan perbaikan pada siklus berikutnya, yaitu pada siklus 3 .

Proses pelaksanaan pada siklus 3 adalah menindaklanjuti kekurangan yang terdapat pada tindakan siklus 2, dimana hasil tindakan dinyatakan belum adanya peningkatan dan belum mencapai ketuntasan. hasil observasi pelaksanaan pembelajaran pada siklus 3 yang diamati oleh peneliti sendiri, dapat peneliti uraikan pada tabel berikut ini.

Tabel 3. Keaktifan Siswa dalam Proses Pembelajaran Menganalisis Unsur-unsur Pembangun Cerpen Melalui Model Discovery Learning Pada Tindakan Siklus 3

\begin{tabular}{|c|c|c|c|}
\hline \multirow{2}{*}{ No. } & \multirow{2}{*}{ Keterlibatan Siswa dalam Pembelajaran } & \multicolumn{2}{|c|}{ Siklus 3} \\
\hline & & Jumlah Siswa & Persentase \\
\hline 1 & Terlibat Aktif & 29 & $96,67 \%$ \\
\hline 2 & Terlibat Pasif & 1 & $3,33 \%$ \\
\hline 3 & Tidak Terlibat & 0 & $0,00 \%$ \\
\hline & Jumlah & 30 & $100 \%$ \\
\hline
\end{tabular}

Berdasarkan hasil observasi keaktifan dalam pembelajaran menganalisis unsur-unsur pembangun cerpen melalui model discovery learning pada siswa pada siklus 3 dapat dikatakan bahwa proses pembelajaran yang disampaikan sudah dapat dipahami oleh siswa. Diketahui siswa yang terlibat aktif sebanyak 29 orang siswa 
atau rata-rata keaktifan sebesar $96,67 \%$. Siswa yang terlibat pasif 1 orang siswa atau rata-rata keaktifan sebesar $3,33 \%$. Sedangkan siswa yang tidak terlibat tidak ada.

Berdasarkan hasil tes kemampuan menganalisis unsur-unsur pembangun cerpen melalui model discovery learning pada siswa pada siklus 3, diperoleh nilai sejumlah 2380 dengan rata-rata 79,33. Siswa yang tuntas dalam pembelajaran berdasarkan KKM ( $\geq 70$ ) sebanyak 29 orang siswa dengan rata-rata ketuntasan siswa sebesar 96,67\%. Artinya dalam tindakan siklus 3 kemampuan menganalisis unsur-unsur pembangun cerpen melalui model discovery learning pada siswa kelas XI IPS-3 SMA Negeri 1 Tanjung Batu sudah dapat dikatakan meningkat dan ketuntasan secara klasikal yaitu 85\% dikatakan sudah tercapai (Ramdhani dkk, 2017).

Beberapa faktor pendukung keberhasilan tindakan yang dicapai pada siklus 3 ini, di mana peneliti lebih memfokuskan pada model discovery learning. Proses pembelajaran menggunakan model discovery learning ini adalah memahami konsep, arti, dan hubungan melalui proses intuitif untuk akhirnya sampai kepada suatu kesimpulan. Discovery terjadi bila individu terlibat terutama dalam penggunaan proses mentalnya untuk menemukan beberapa konsep dan prinsip (Desyandri dkk, 2019). Model discovery learning dapat meningkatkan kemampuan siswa dalam menganalisis unsur-unsur pembangun cerpen begitu juga dengan mata pelajaran lain (Elizar dkk, 2018; Abrahamson dan Kapur, 2018; Roza dkk, 2018).

\section{Simpulan}

Berdasarkan hasil penelitian tindakan kelas terhadap kemampuan menganalisis unsur-unsur pembangun cerpen melalui model discovery learning pada siswa kelas XI IPS-3 SMA Negeri 1 Tanjung Batu yang dilaksanakan sebanyak 3 siklus dapat disimpulkan bahwa model pembelajaran discovery learning dapat meningkatkan kemampuan menganalisis unsur-unsur pembangun cerpen siswa kelas XI IPS-3 SMA Negeri 1 Tanjung Batu dengan hasil yang dicapai pada siklus 1 nilai rata-rata 67,83 dengan persentase ketuntasan sebesar 46,65\%, pada siklus 2 nilai rata-rata diperoleh 71,17 dengan persentase ketuntasan sebesar $80 \%$, dan siklus 3 mengalami peningkatan signifikan dimana hasil nilai rata-rata 79,33 dengan persentase ketuntasan sebesar $96,67 \%$.

\section{Referensi}

Abrahamson, D., \& Kapur, M. (2018). Reinventing discovery learning: a field-wide research program. Instructional Science, 46(1), 1-10.

Amirullah, K. A. S. (2019). Peningkatan Kemampuan Menganalisis Unsur Instrinsik Cerpen Melalui Pembelajaran Inkuiri pada Siswa Kelas IX SMP. Jurnal Riset Teknologi dan Inovasi Pendidikan, Vol. 2 No. 1, hal. 126-138.

Darmawan, D., \& Wahyudin, D. (2018). Model Pembelajaran di Sekolah. Bandung: Remaja Rosdakarya.

Desyandri, D., Muhammadi, M., Mansurdin, M., \& Fahmi, R. (2019). Development of integrated thematic teaching material used discovery learning model in grade V elementary school. Jurnal Konseling Dan Pendidikan, 7(1), 16-22.

Effendi, D. (2019). Pandangan Dunia Pengarang dalam Novel Bulan Terbelah di Langit Amerika Karya Hanum Salsabiela Rais dan Rangga Almahendra serta Implikasinya dalam Pengajaran Sastra. Jurnal Diksa: Pendidikan Bahasa dan Sastra Indonesia, Vol. 5 No. 2.

Ellizar, E., Hardeli, H., Beltris, S., \& Suharni, R. (2018, April). Development of scientific approach based on discovery learning module. In IOP Conference Series: Materials Science and Engineering (Vol. 335, No. 1, p. 012101). IOP Publishing.

Kosasi, E. (2010). Apresiasi Sastra Indonesia. Jakarta: Novel Edumedia.

Mulyadi. (2016). Intisari Sastra Indonesia untuk SMP dan SMA. Bandung: Yrama Widya.

Nabila, Y. (2018). Penggunaan Model Pembelajaran Discovery Learning dalam Peningkatan Hasil Belajar Siswa di Sekolah Dasar. Jurnal Ilmiah Pendidikan dan Pembelajaran, Vol 2, No 1.

Purnami, S. (2012). Peningkatan Kemampuan Menganalisis Unsur Intrinsik Cerpen Melalui Metode Diskusi Jenis Buzz Group Pada Siswa Kelas VIII-A SMP Dwijendra Gianyar Tahun Pelajaran 2011/2012. Jurnal Bastra, Vol 4, No 3, hal 337-353.

Rahmanto. (2010). Struktur Karya Sastra. Jakarta: Dian Pustaka.

Ramdhani, M. R., Usodo, B., \& Subanti, S. (2017, September). Discovery learning with scientific approach on geometry. In Journal of Physics: Conference Series (Vol. 895, No. 1, p. 012033). IOP Publishing.

Roza, N., Arnawa, I., \& Yerizon, Y. (2018). Practicality of mathematics learning tools based on discovery learning for topic sequence and series. International Journal of Scientific dan technology Research, 7(5), 236241.

Sadikin, M. (2010). Kumpulan Sastra Indonesia. Jakarta: Gudang Ilmu. 
Sardiman. (2012). Interaksi dan Motivasi Belajar Mengajar. Jakarta: Rajawali Pers.

Sugiyono. (2015). Metode Penelitian Pendidikan, Pendekatan Kuantitatif, Kualitatif, dan $R$ dan D. Bandung: Alfabeta.

Suhita, S., \& Purwahida, R. (2018). Apresiasi Sastra Indonesia dan Pembelajarannya. Bandung: Remaja Rosdakarya.

Suherli. (2017). Bahasa Indonesia. Jakarta: Intan Pariwara.

Wijaya, T. (2019). Panduan Praktis Menyusun Silabus, RPP, dan Penilaian Hasil Belajar. Yogyakarta: Noktah. 